\title{
HISTORY OF MEDICINE
}

\section{Sir Henry Halford, president of the Royal College of Physicians, with a note on his involvement in the exhumation of King Charles I}

\author{
John S Morris
}

Postgrad Med J 2007;83:431-433. doi: 10.1136/pgmi.2006.055848

Henry Halford (formerly Vaughan) (1766-1844) was president of the Royal College of Physicians for an unprecedented 24 years. A successful physician, he had to resign his post at the Middlesex Hospital because of his growing private practice. He was physician to four reigning monarchs and had many famous patients including Geogiana Duchess of Devonshire in whom he correctly diagnosed a liver abscess when other physicians had failed. He was also involved in the exhumation of King Charles I, and the fourth cervical vertebra, through which the King had been executed, came into his possession.

Correspondence to: Dr John S Morris, 84 Park Street, Bridgend, CF31 4 BB, UK; JSMogwr@aol.com

Received

26 November 2006

Accepted 12 January 2007
$\mathrm{S}$ ir Henry Halford, previously Henry Vaughan (1766-1844) (fig 1), was president of the Royal College of Physicians from 1820 until his death-a period of 24 years. Born in Leicester, his father James Vaughan was an accomplished physician of the town and his mother, Hester, was the daughter of William Smalley who had married a daughter of Sir Richard Halford. ${ }^{1}$ James Vaughan was an exceptional man, investing all his income on the education of his children. Rather graphically he said that he would prefer to follow them to their grave were they not successful in their chosen calling. ${ }^{2}$ James Vaughan lived to see the success of his son Henry, and for many years received from him an annuity of $£ 300 .^{2}$ Henry Vaughan was educated at Rugby, matriculating in Christ Church Oxford and graduating BA in 1788, MB in 1790 and DM in $1791^{1}$

On leaving Oxford Henry Vaughan studied in Edinburgh for three sessions, each of 6 months, in between times returning to Leicester where he learned clinical medicine from his father. Qualifying in medicine he spent some time practising in Scarborough and in 1792 decided to move to London where he sought the advice of Sir George Baker, the then president of the Royal College of Physicians. ${ }^{2}$ Baker advised him that he needed an income of $£ 300$ a year in order to establish himself in the city.

Confident of his ability to succeed he borrowed $£ 1000$ and set up in London. ${ }^{3}$ Success quickly came and in 1793 he was elected physician to the Middlesex Hospital, a post he gave up in 1800 because of his growing private practice.

In March 1795 he married the Hon Elizabeth Barbara St John, the third daughter of Lord St John of Bletsoe. They had two children, a son and a daughter. Halford's wife died in 1833.
Within a year of his arrival in London Halford's star was in the ascendant. He was appointed physician extraordinary to the King. He also inherited a large estate on the death of Lady Denbigh, the widow of his mother's cousin Sir Charles Halford. In anticipation of succeeding to the estate Henry Vaughan changed his name to Halford by Act of Parliament in 1809. George III made him a baronet in the same year and Halford subsequently became physician to George IV, William IV and Victoria. In 1810 he was elected FRS $^{1}$

\section{HALFORD AS A PHYSICIAN}

What led to Halford's success? He certainly had a charming bedside manner. Roy Porter writes "... so suave was his bedside manner that aristocratic women were said to prefer dying with Sir Henry than living with lesser physicians ${ }^{\prime \prime} .{ }^{4} \mathrm{He}$ had his detractors. JF Clarke called him vain, cringing to his superiors and haughty to his inferiors. ${ }^{5}$ James Wardrop, surgeon to George IV, called him the "eel backed Baronet". ${ }^{1}$ Wardrop's opinion, however, is tainted by the fact that he criticised many of the medical members of the court and the King excluded him from his deathbed, preferring the attentions of Halford. ${ }^{6}$ Queen Adelaide acknowledged Halford's bedside manner but was less sure of his clinical expertise. Although Halford was her personal physician, when the queen became ill in 1836 she sought the advice of Dr W F Chambers of St George's. ${ }^{7}$ Additionally, much to Halford's annoyance, she bypassed him in favour of Chambers when King William became ill in the final year of his life

As a physician Halford knew little of the basic sciences and eschewed recent advances in medicine. He is reported never to have used a stethoscope. $^{8}$ The stethoscope could not have been known to Halford until 1820 when he would have been 54 years old-late in life to embrace innovation." The Lancet wrote " ...he is all tact and nothing else. He is ignorant of recent discoveries...he has never written a line that is worthy of perusal on any scientific subject". ${ }^{7}$

Despite adverse criticism Halford was a successful physician. His philosophy seems to have been that the responsibility of a doctor was to make the patient feel better regardless of the precise diagnosis. His reputation was enhanced in 1804.

Geogiana, Duchess of Devonshire and a renowned beauty, developed a fever the cause of which was undetermined. Halford was consulted, 


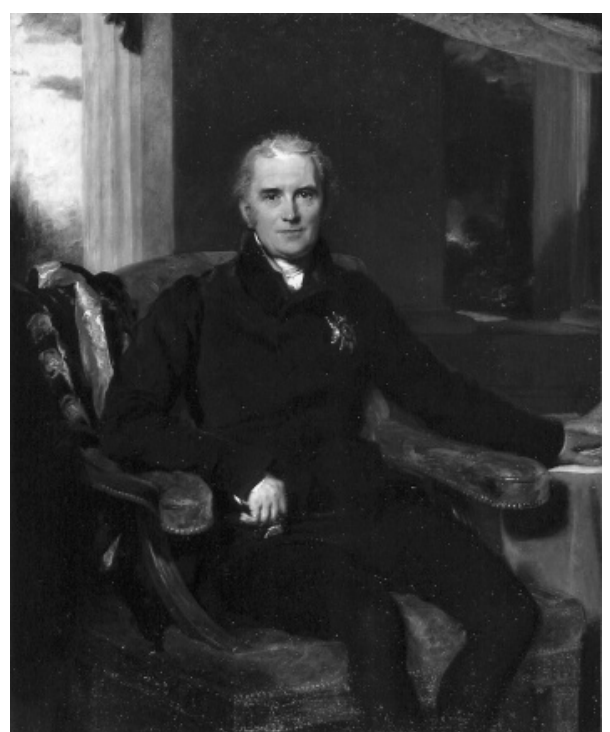

Figure 1 Portrait of Sir Henry Halford. Reproduced with permission, copyright Royal College of Physicians, London.

noticed jaundice and tenderness over the liver, and diagnosed a liver abscess. At post mortem examination gallstones were found and, as Halford had predicted, there were collections or abscesses in the liver. ${ }^{2}$

Following this his popularity grew and he became physician to the rich and famous. He also attended George III and was present with others (Dr Baillie, Dr Heberden, Dr Robert Willis and Sir David Dundas) at his death in January $1820 .^{2}$ Halford had become the King's physician at the request of the Queen and the Prince of Wales who had had become increasingly disturbed by Willis and his family, the King's then medical advisors, whose policy of restraint in the management of the King was thought inhumane. ${ }^{10}$ Halford, Baillie and Heberden adopted a more conservative approach, Halford even suggesting that the King's symptoms were the result of ageing-"The Climacteric Disease" ${ }^{11}$ In modern day terms this would be considered discrete even if his diagnosis was wrong. In fairness to Halford, in a hand written note he commented that the King's urine remained "... of a deeper colour..." in keeping with the current diagnosis of porphyria. ${ }^{10} \mathrm{He}$ also pointed out the King's constipation and vomiting symptoms, again compatible with a diagnosis of porphyria. ${ }^{12}$ Halford also treated George IV. In a note to the prime minister, the Duke of Wellington, in the King's final illness Halford considered that the fluid retention, which was evident in his limbs, had spread to the pericardium and the lungs.

Halford's clinical observations were confirmed at post mortem examination. The likelihood is that the King had calcific aortic stenosis. These comments arise from a careful examination of the Royal Archives by Rohl and his colleagues. ${ }^{13}$

Halford wrote little and is not recorded as an experimenter or an observer. He did, however, publish one volume entitled "Essays and orations", which was based largely on talks that he had given at the College of Physicians and included an account of the opening of the tomb of King Charles.$^{14}$

\section{HALFORD AND THE ROYAL COLLEGE OF PHYSICIANS}

Halford's first connection with the Royal College of Physicians (RCP) was not a happy one. As president of the London Medical and Chirurgical Society, Halford petitioned the crown to grant a Royal Charter. The RCP were suspicious of this, fearing that some of their privileges might be jeopardised. They bitterly opposed that petition and also a further one to the Privy Council that was signed by three fellows of the Royal College of Physicians, including Halford. The RCP even accused Halford of acting fraudulently by using his position as a Fellow to support the petition. ${ }^{15}$ Despite this early disagreement with the RCP, Halford became president of the Royal College in 1820 and remained president until his death in 1844 . He was instrumental in moving the College from Warwick Lane to newly built accommodation in Pall Mall East. Halford also instituted monthly evening meetings for the first 6 months of each year. The meetings attracted both a professional and a lay audience.

As president of the RCP, Halford was involved in the planning of the defence against cholera. When the possibility that cholera may break out in 1830 the Privy Council sought the advice of Halford and the College of Physicians. Halford considered that the disease was contagious but could not be carried by goods. Halford became president of a board of health, which consisted of 12 members. The remit of the board was to monitor cholera, educate the public, and suggest remedies. The board of health set up a network of health boards across the country, which had similar terms of reference but in particular relayed statistics to the central authority. The board of health did not last long and was superseded by a central board of health in which Sir Henry played no part. ${ }^{2}$ Again the Lancet was critical of Halford, writing "How the mighty have fallen! The secret-bulletin writer to His Majesty George IV - Physician General to the court of St James - 'Professor' Manufacturer to the King's College - poor Sir Henry Halford has at last dropped down to his legitimate level... and all at once has sunk from the Council Chamber to the dirty 'Hall' in Pall Mall East". ${ }^{16}$

Halford was a keen advocate of vaccination following its introduction by Jenner in 1798. As president of the RCP he became ex-officio president of the National Vaccine Establishment, a role which he pursued with enthusiasm. ${ }^{2}$ So highly did he rate vaccination as a means of avoiding or modifying smallpox he was instrumental in appointing Dr Jenner as physician extraordinary to King George IV. ${ }^{2}$

\section{HALFORD AND THE EXHUMATION OF CHARLES I}

Following the execution of Charles I on 30 January 1649 parliament was anxious to avoid his martyrdom and a state burial in Westminster Abbey was denied. ${ }^{1}$ The day following his execution his head was sewn back on and the body transferred by boat to Windsor. There he was buried with little ceremony on 8 February. There was uncertainty as to the precise location of the tomb. Although Mr Herbert, valet to Charles I, knew the body had been interred in the tomb of Henry VIII, this information was only revealed after the death of Herbert in the beginning of the next century. ${ }^{14}$ During the construction of a tomb house in St George's chapel at Windsor, workmen came across the tomb of Henry VIII in which there were three coffins. The largest was assumed to belong to Henry VIII, a smaller one was thought to contain Jane Seymour, and a third coffin covered in a black pall was assumed to contain the body of Charles I. The Prince Regent saw this as an opportunity to identify the resting place of the King and instructed that the coffin be opened.

On 1 April 1813 the coffin was opened in the presence of the Prince Regent, the Duke of Cumberland, Count Munster, the Dean of Windsor, Benjamin Charles Stevenson and Sir Henry Halford.${ }^{14}$ Halford gives a full account of the findings in his essay. ${ }^{14}$ The identity of the body was proved by the simple inscription "King Charles 1648" on the coffin lid and by evidence of decapitation in which the fourth cervical vertebra had been cut through "...its substance transversely, leaving the surfaces of the divided portions perfectly smooth and even, an appearance which could have been produced only by a heavy 
blow, inflicted by a very sharp implement". ${ }^{14}$ The purpose of the exhumation satisfied, the parts were returned to the coffin which was then closed.

The coffin having been closed the fourth cervical vertebra was retained and came into the possession of Halford who had it mounted and used to show it as a curiosity to his dinner guests. Halford gave a detailed account to his grandson of how he came by the vertebra, saying that after the coffin had been closed three items were not replaced-the half vertebra, a tooth, and a portion of King Charles' beard. The Prince Regent said that it was not worth re-opening the coffin, and handing them to Halford said, "...these are more in your line than mine, you had better keep them". ${ }^{\prime}$

The medical gossip Clarke gives a different account, obtained from "...a physician of high repute...now lately deceased". Clarke wrote, "Halford found means to detach and purloin that portion of the fourth cervical vertebra which had been cut through by the axe; that he kept it as a curiosity; used to pass it around the dinner table after dinner for the examination of his guests."

This latter account implies a criminal act by Halford, an offence that was also cited by Hill. ${ }^{3}$ Newman wrote in Halford's defence. He points out that the number of people present would have made it difficult, if not impossible, for Halford to secrete the artefact; additionally Dean Legge gave him a piece of paper in which to wrap the artefacts which bore the Dean's address, and this was noted by Dean Davidson when preparing a box for the relics before its reburial. ${ }^{9}$

The implication is that Halford obtained the vertebra by honest means. He treated it with reverence and constructed a box made of lignum vitae with the inscription "...see the very neckbone of King Charles I, alas cut off by iron (a sword) 1648 and in addition the Royal Beard". ${ }^{17}$ (The year 1648 is quoted both by Munk ${ }^{2}$ and Halford ${ }^{14}$ and is clearly an error.)

With the death of Sir Henry, his grandson Sir Henry St John Halford, the third baronet, inherited the relics. He and his brother had no heirs so they were concerned as to what might become of them. Halford's grandson decided that they should be returned to the Royal family. The Prince of Wales received the relics apparently reluctantly. ${ }^{9}$ With Queen Victoria's permission the relics were replaced in the coffin of King Charles I. The Dean of Windsor had a leaden casket prepared which had the following inscription: "The relics in this case were taken from the coffin of King Charles I on April $1^{\text {st }} 1813$, by Sir Henry Halford, Physician to King George III. They were by his grandson Sir Henry St. John Halford given to H.R.H. Albert Edward, Prince of Wales. On December $13^{\text {th }} 1888$ they were replaced by H.R.H. in this vault, their original resting place." ${ }^{17}$

\section{CONCLUSIONS}

Sir Henry Halford, despite his detractors, was clearly a respected physician. He apparently knew little of the basic sciences but was an accomplished Latin scholar, in his later years composing verse in Latin. Like many famous men he was maligned by those envious of him. The serious charge that he "purloined" the fourth cervical vertebra of King Charles I cannot be substantiated. Halford died at his home in Curzon Street, Mayfair, and was buried in the parish church at Wistow-his country seat. A memorial to him was erected there. ${ }^{1}$

\section{ACKNOWLEDGEMENTS}

I am indebted to the librarians at the Princess of Wales Hospital, Bridgend for their help in retrieving references.

Conflict of interest: none stated

\section{REFERENCES}

1 Bettany GT, Bevan M. Halford, Sir Henry, first baronet (1766-1844). Oxford: Oxford Dictionary of National Biography, OUP, 2004-2007.

2 Munk W. The life of Sir Henry Halford, Bart. 1895, London: Longmans, Green and $\mathrm{Co}$ ).

3 Hill B. The friend of the Royal Family. Practitioner 1966;197:696-701.

4 Porter R. The greatest benefit to mankind. London: Harper Collins, 1997.

5 Clarke JF. Autobiographical recollections of the medical profession. London: J\&A Churchill New Burlington Street, 1874.

6 Millar G. James Wardrop (1782-1869): from Whitburn to Windsor Castle. $J R$ Coll Surg Edinb 2001;46:223-5.

7 Whitefield A. The Gentle Queen. J R Coll Physicians Lond 1986;20:63-6.

8 Fleming P. A short history of cardiology. Amsterdam, Atlanta, Georgia: Clio Medica, 1997.

9 Newman CE. The fourth cevical vertebra of Charles I. J R Coll Physicians Lond $1979 ; 13: 221-3$

10 Macalpine I, Hunter R. George III and the Mad-Business. London: Pimlico, 1991.

11 Livesley B. The Climacteric Disease. J Am Geriatr Soc 1977;25:162-6.

12 Arnold WN. King George III's urine and indigo blue. Lancet 1996:347:1811-13.

13 Rohl J, Warren M, Hunt D. Purple Secret. London: Bantam Press, 1998.

14 Halford SH. Essays and orations. London: John Murray, 1831.

15 Hunting P. The history of the Royal Medical Society of London. London: Royal Society of Medicine Press, 2002.

16 Hunt T. Introduction to Macmichael W. The Gold Headed Cane a facsimile of the 1827 copy. London: Royal College of Physicians, 1968.

17 Partridge RB. O Horrable Murder. London: The Rubicon Press, 1998.

Correction

doi: 10.1136/pmi.2006.047381 corr 1

D J M Macdonald, C J Tollan, I Robertson, et al. Massive haemorrhage after a low-energy pubic ramus fracture in a 71-year-old woman. (Postgrad Med J 2006;82:e25). In this article the fourth author appears as B S Rana; the author usually uses B Rana as his publishing name. 